\title{
CONSTRUCTION WASTE AND ITS RECYCLING
}

\author{
Aadu Vôsu \\ Ragn Sells Eesti Ltd. \\ Estonia
}

Estonian economy has developed rapidly during last years. It is applies also in building and construction industry. Table 1 gives a survey of investments made by Estonian building companies during the last five years.

Table 1: Investments in construction (1992-1996, million crowns) (1)

\begin{tabular}{|c|l|l|l|l|l|}
\hline year & 1994 & 1992 & 1995 & 1993 & 1996 \\
\hline investment & 1109 & 3931 & 1906 & 5664 & 3097 \\
\hline
\end{tabular}

As a result of economical growth the volume of different types of waste in Tallinn and in whole Estonia has changed dramatically as well. A recent extensive developments in building and reconstruction indicated the massive quantities of refuse generated by building and construction industry.

By estimations about $45 \%$ of all waste going to landfill arises from construction and that approximately $75 \%$ of this construction waste has the potential to be reused as fill or aggregate.

Waste collecting and transporting company "Ragn Sells Eesti Ldt" Tallinn department collecting an average $4000 \mathrm{~m}^{3}$ or $6400 \mathrm{t}$ (volume weight $1,6 \mathrm{~kg} / \mathrm{m}^{3}$ ) of construction waste monthly.

From January to March 1996 has been experimentally separated approximately $2300 \mathrm{~m}^{3}$ (wich corresponds $3680 \mathrm{t}$ ) of construction waste. All waste has been collected from different regions of Tallinn. The first selection was made by collecting vehicle driver. For manual and partly mechanical separation was transported only conteiners which consisted of different recyclable materials like wood, metal, concrete, cardboard, glass ect.

The results of separation are presented in table 2 . 
Table 2: The results of separation

\begin{tabular}{|c|c|c|c|c|c|c|}
\hline $\begin{array}{c}\text { Recycled } \\
\text { material }\end{array}$ & Wood & Metal & $\begin{array}{c}\text { Waste } \\
\text { paper }\end{array}$ & Filler & Glass & Land filled \\
\hline Tonnes & 107 & 24 & 3 & 1886 & 2 & 1794 \\
\hline$\%$ & 2 & $<1$ & $<1$ & 51 & $<1$ & 47 \\
\hline
\end{tabular}

The key to successful recycling is meeting the needs of the market. But Estonian market for recyclable materials is at the moment very poor. No apparent problems with steel, black and colored metal and whitepaper, but more difficult to find users for wastewood as well for filler.

Taxation seems to be as one means of encouraging a better use of recycling building materials most of which (generated in 1995198024 t) (2) goes to landfill at present.

\section{REFERENCES}

1. Estonian Building Market 1997 . Handbook, Tallinn ,edited by Ü.Siinmaa

2. Estonian Environment 1995. Yearbook, Ministry of the Environment of Estonia, 1996 Tallinn 